\title{
Molybdenum on solid support materials for catalytic hydrogenation of $\mathrm{N}_{2}$-into- $\mathrm{NH}_{3}$
}

\author{
Luis Miguel Azofra, ${ }^{*[a]}$ Natalia Morlanés,${ }^{[a]}$ Albert Poater,${ }^{[b]}$ Manoja K. Samantaray, ${ }^{[a]}$ Balamurugan \\ Vidjayacoumar, ${ }^{[c]}$ Khalid Albahily, ${ }^{[c]}$ Luigi Cavallo ${ }^{*[a]}$ and Jean-Marie Basset ${ }^{*[a]}$
}

\begin{abstract}
Very stable in-operando and low-loaded atomic molybdenum on solid support materials have been prepared and tested to be catalytically active for $\mathrm{N}_{2}$-into- $\mathrm{NH}_{3}$ hydrogenation. Ammonia synthesis is reported at atmospheric pressure and $400^{\circ} \mathrm{C}$ with $\mathrm{NH}_{3}$ rates of ca. $1.3 \cdot 10^{3} \mu \mathrm{mol} \mathrm{h}^{-1} \mathrm{~g}_{\mathrm{Mo}}{ }^{-1}$ using a well-defined Mohydride grafted on silica $\left(\mathrm{SiO}_{2-700}\right)$. DFT modelling on the reaction mechanism suggests that $\mathrm{N}_{2}$ spontaneously binds on monopodal $\left[(\equiv \mathrm{Si}-\mathrm{O}-) \mathrm{MoH}_{3}\right]$. Based on calculations, the fourth hydrogenation step involving the release of the first $\mathrm{NH}_{3}$ molecule represents the rate-limiting step of the whole reaction. The inclusion of cobalt cocatalyst and an alkali caesium additive impregnated on mesoporous SBA-15 support increases the formation of $\mathrm{NH}_{3}$ with rates of ca. $3.5 \cdot 10^{3} \mu \mathrm{mol} \mathrm{h} \mathrm{h}^{-1} \mathrm{gmo}^{-1}$ under similar operating conditions and maximum yield of $29 \cdot 10^{3} \mu \mathrm{mol} \mathrm{h}^{-1} \mathrm{gMo}_{\mathrm{Mo}}^{-1}$ when pressure is increased to $30 \mathrm{~atm}$.
\end{abstract}

Ammonia $\left(\mathrm{NH}_{3}\right)$ synthesis is amongst the most globally important processes in the chemical industry due to the use of $\mathrm{NH}_{3}$ as the source of most fertilisers. ${ }^{[1]}$ According to data provided by L. E. Apodaca, ${ }^{[2]} 2013$ worldwide production of $\mathrm{NH}_{3}$, with China, India, the Russian Federation, the United States and the European Union at the top of producers, reached 0.14 Gton. Since it is estimated that $3 \%$ of the global $\mathrm{CO}_{2}$ emissions into the atmosphere are due to industrial, large-scale $\mathrm{NH}_{3}$ synthesis, ${ }^{[3]}$ this supposes the release of approximately 1 billion tonnes of $\mathrm{CO}_{2}$ residues per year. ${ }^{[4]}$ Against this background, the environmental impact of $\mathrm{NH}_{3}$ synthesis certainly deserves special attention.

Although Nobel laureate Fritz Haber ${ }^{[5]}$ reported the use of osmium (also uranium) as the first industrial catalyst for $\mathrm{NH}_{3}$ synthesis from air-source dinitrogen $\left(\mathrm{N}_{2}\right)$, the scarcity of this rare metal meant that the only alternative until the mid-80s of the last century was based on iron oxide ${ }^{[6]}$ materials. These provided stable activities during reaction and practically unlimited access

[a] Dr. L. M. Azofra, Dr. N. Morlanés, Dr. M. K. Samantaray, Prof. Dr. L. Cavallo, Prof. Dr. J.-M. Basset

KAUST Catalysis Center (KCC)

King Abdullah University of Science and Technology (KAUST)

Thuwal 23955-6900 (Saudi Arabia)

E-mail: luis.azoframesa@kaust.edu.sa, luigi.cavallo@kaust.edu.sa, jeanmarie.basset@kaust.edu.sa

[b] Dr. A. Poater

Institut de Química Computacional i Catàlisi

Departament de Química, Universitat de Girona

Campus de Montilivi, s/n, 17003 Girona, Catalonia (Spain)

[c] Dr. Balamurugan Vidjayacoumar, Dr. Khalid Albahily

SABIC (Saudi Basic Industries Corporation)

King Abdullah University of Science and Technology (KAUST)

Thuwal 23955-6900 (Saudi Arabia)

Supporting information for this article is given via a link at the end of the document. due to the low-cost and abundance of Fe ores. However, the very harsh operating conditions, with temperatures around 350$525^{\circ} \mathrm{C}$ and pressures varying between 10-30 MPa (100-300 atm) of Fe-based Haber-Bosch catalytic $\mathrm{NH}_{3}$ synthesis, ${ }^{[7]}$ ask for the searching of new alternatives. To date, ruthenium ${ }^{[8]}$ has been profiled as the only realistic replacement. Although operating conditions can be decreased to $325-450^{\circ} \mathrm{C}$ and $\leq 10$ $\mathrm{MPa}$, methanation of the carbon material from the carriers in the $\mathrm{Ru}$ catalyst under ammonia synthesis conditions results, however, in a loss of active carbon carrier and the shortening of the lifetime of the catalyst. In addition to this and even though $\mathrm{Ru}$ is more economically accessible than other precious metals (such as gold or platinum), current market price has practically quadrupled with respect to one year ago (65 \$/ozt at $1^{\text {st }}$ May ' 17 , while 250 \$/ozt at $1^{\text {st }}$ May '18). ${ }^{[9]}$

In an attempt to design new strategies for $\mathrm{N}_{2}$-into- $\mathrm{NH}_{3}$ conversion, well-defined single-site heterogeneous catalysts ${ }^{[10]}$ deserve special attention since they have proven to be effective catalysts for several reactions such as olefin ${ }^{[11]}$ or $n$ - and branched alkane metathesis, ${ }^{[12]}$ amongst other outstanding transformations. (Cycloisomerisation of alkynes, Ziegler-Natta polymerisation, imine metathesis or alkane hydrogenolysis, are some of many other examples). ${ }^{[10]}$ In 2007 we reported $\mathrm{N}_{2}$ dissociation and hydrogenation on an isolated surface tantalum atom supported on silica, $\left(\mathrm{SiO}_{2-700}\right),{ }^{[13]}$ a work that later inspired Li et al. ${ }^{[14]}$ and Eisenstein and co-workers ${ }^{[15]}$ in the elucidation of the mechanism through a DFT approach. They hypothesised that the formation of the $\left[(\equiv \mathrm{SiO}-)_{2} \mathrm{TaH}-\left(\mathrm{NH}_{2}\right)_{2}\right]$ species by hydrogenation of $\left[(\equiv \mathrm{SiO}-)_{2} \mathrm{TaH}-\left(\eta^{2}-\mathrm{N}_{2}\right)\right]$ followed an associative mechanism that releases ca. $90 \mathrm{kcal} \mathrm{mol}^{-1}$. Although these works helped to understand the chemistry of $\mathrm{N}_{2}$ activation and hydrogenation by well-defined single-site Ta-hydrides on silica, $\mathrm{NH}_{3}$ synthesis was not reported due to the high stability of the aminidated Ta centre. Amongst the variety of alternatives, molybdenum might exhibit promising prospects for total conversion of $\mathrm{N}_{2}$ into $\mathrm{NH}_{3}{ }^{[16]}$

Herein, we present experimental evidence supported by theoretical mechanistic interpretations for catalytic $\mathrm{NH}_{3}$ synthesis by single-site molybdenum hydride on silica, reporting, for the first time, the capabilities of these kinds of materials as $\mathrm{N}_{2}$ fixation catalysts. Based on these findings, we also propose other molybdenum on solid support materials with higher rates of $\mathrm{NH}_{3}$ production in the presence of a cobalt co-catalyst and an alkali caesium additive.

The so-called "Mo-neopentyl" on silica material (MoNp), ${ }^{[17]}$ corresponding to $\left[(\equiv \mathrm{Si}-\mathrm{O}-) \mathrm{Mo}\left(\equiv \mathrm{C}_{-}{ }^{t} \mathrm{Bu}\right)(\mathrm{Np})_{2}\right]$, was prepared by reaction of a solution of $\mathrm{Mo}\left(\equiv \mathrm{C}^{-} \mathrm{Bu}\right)(\mathrm{Np})_{3}$ in pentane with partially dehydroxylated silica at $700^{\circ} \mathrm{C}$, Aerosil $\circledast \mathrm{SiO}_{2-700}$, during $2 \mathrm{~h}$ at room temperature conditions (see Scheme 1). After reaction, the resulting light brown solid was washed with pentane $(3 \times 20 \mathrm{~mL})$ and dried under dynamic vacuum to get 


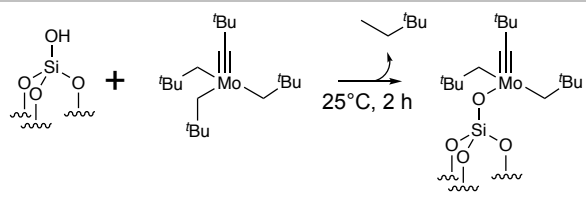

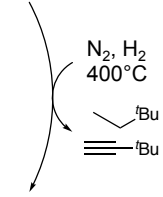

Scheme 1. Schematic experimental procedure for $\left[(\equiv \mathrm{Si}-\mathrm{O}-) \mathrm{Mo}\left(\equiv \mathrm{C}^{-} \mathrm{Bu}\right)(\mathrm{Np})_{2}\right]$ synthesis and proposed mechanism for $\mathrm{N}_{2}$-into- $\mathrm{NH}_{3}$ conversion by chemical hydrogenation under $400^{\circ} \mathrm{C}$ and $1 \mathrm{~atm}$ operating conditions.

the light brown powder corresponding to the formula [( $\equiv \mathrm{Si}-\mathrm{O}$ ) $\left.\mathrm{Mo}\left(\equiv \mathrm{C}-{ }^{\mathrm{t}} \mathrm{Bu}\right)(\mathrm{Np})_{2}\right]$

Fourier-Transform Infrared (FTIR) spectroscopy analysis (see Fig. S4 in the Supporting Information, $\mathrm{SI}$ ) on this material reveals the presence of several peaks associated to $\mathrm{C}-\mathrm{H}$ stretching $\left(2953,2900,2866 \mathrm{~cm}^{-1}\right)$ and bending $(1465,1354$ $\mathrm{cm}^{-1}$ ) modes. Liquid-state ${ }^{1} \mathrm{H}$ NMR spectrum for Schrock Mo( $\equiv$ $\left.\mathrm{C}-{ }^{t} \mathrm{Bu}\right)(\mathrm{Np})_{3}$ complex shows three peaks at $1.4,1.3$ and $1.0 \mathrm{ppm}$ corresponding to $\mathrm{CH}_{2}$ and $\mathrm{CH}_{3}$ protons in $\equiv \mathrm{C}-{ }^{t} \mathrm{Bu}$ and neopentyl moieties. The further confirmation comes from ${ }^{13} \mathrm{C} N M R$ spectrum, revealing the most characteristic peak at $322 \mathrm{ppm}$ (carbyne) along with other peaks in the region of 87 to $29 \mathrm{ppm}$ for carbons of methylene and ${ }^{t} \mathrm{Bu}$ (see Fig. S6). Solid-state CP/MAS ${ }^{1} \mathrm{H}$ NMR shows a broad peak centred at $1.5 \mathrm{ppm}$ and a shoulder at $1.8 \mathrm{ppm}$, and ${ }^{13} \mathrm{C}$ NMR spectrum reveals three peaks at 89,32 and $29 \mathrm{ppm}$, being assigned by analogy with the ${ }^{13} \mathrm{C}$ spectrum of the parent $\mathrm{Mo}\left(\equiv \mathrm{C}-{ }^{t} \mathrm{Bu}\right)(\mathrm{Np})_{3}$ complex in solution

The MoNp material, kept inside a glove box, was introduced into a stainless-steel cylinder reactor, which remained isolated from the glove box atmosphere, to subsequently place in the setup for the study of the reaction under dynamic conditions. After connecting to the gas lines and purging the tubes, a mixture of $\mathrm{H}_{2}$ and $\mathrm{N}_{2}$ (total flow-rate of 40 $\mathrm{mL} \min ^{-1}, 3: 1 \mathrm{H}_{2}: \mathrm{N}_{2}$ ratio) was introduced onto the catalyst bed (200 mg of catalyst). The reactor outlet was connected to a Mass-Vac Spectrometer for continuous monitoring of the $\mathrm{NH}_{3}$ mass signal. As seen in Scheme 1, the MoNp material is indeed used as precursor, since under $\mathrm{H}_{2}$ and $\mathrm{N}_{2}$ atmosphere and $400^{\circ} \mathrm{C}$, elimination of 2,2-dimethylbutane and 3,3-dimethylbut-1yne groups occur to form the catalytically active Mo hydride $\left(\mathrm{MoH}_{x}\right)$ species. FTIR measurements (at 75 and $100^{\circ} \mathrm{C}$ ) on this material indicate a peak at $1880 \mathrm{~cm}^{-1}$ corresponding to $\mathrm{Mo}-\mathrm{H}$ stretching modes (see Fig. S5).

Fig. 1a indicates $\mathrm{NH}_{3}$ production at different temperatures $\left(400-550^{\circ} \mathrm{C}\right)$ in an experiment carried out during 6 days with temperature changes in intervals of $24 \mathrm{~h}$ and atmospheric pressure. $\mathrm{NH}_{3}$ production rate remains practically constant when operating at a given temperature and this increases when temperature is higher. This reveals a high-stability of the catalytic performance of the $\mathrm{MoH}_{x}$ catalyst, which is also accompanied by a growing accumulated turnover number.

MoNp precursor material is constituted by $2 \mathrm{wt} . \%$ of Mo metal and it is assumed that, as always in surface organometallic chemistry (SOMC) methods of preparation, all
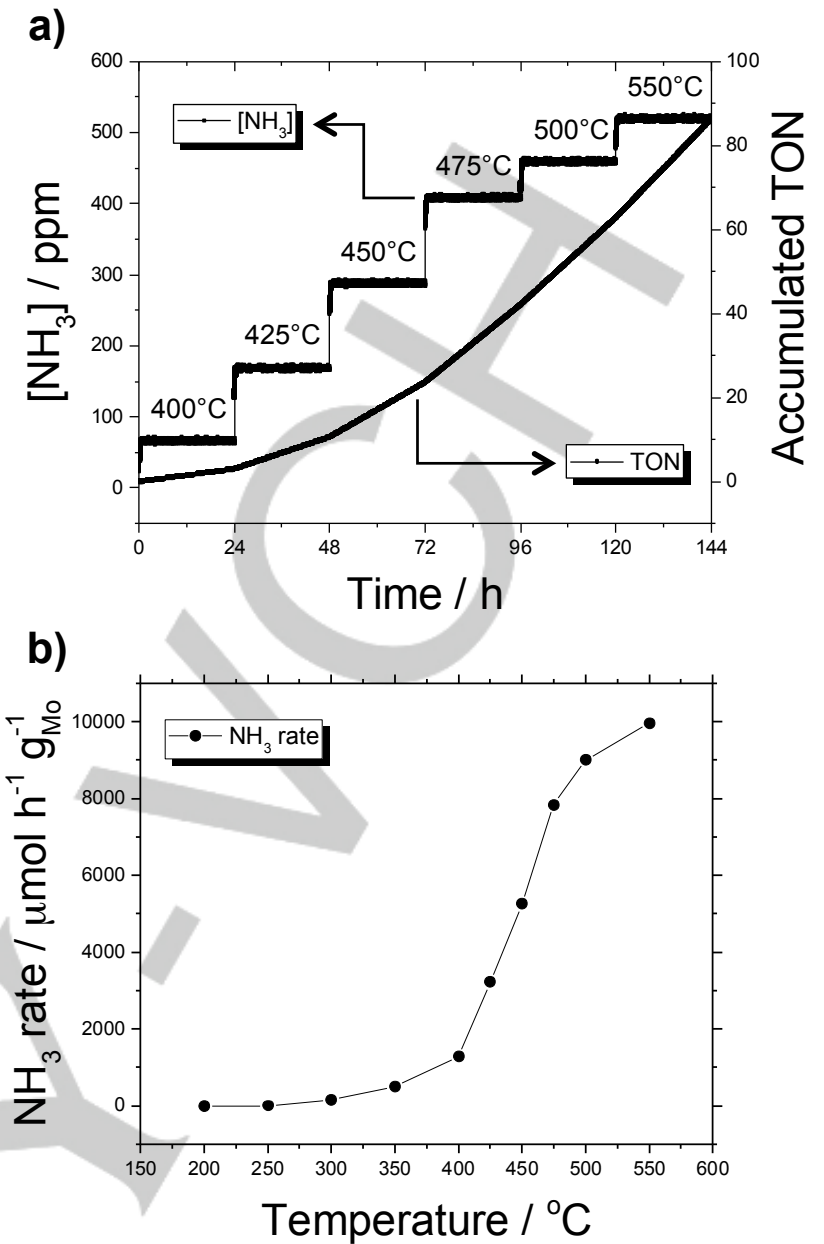

Figure 1. (a) $\mathrm{NH}_{3}$ production, in ppm, at different temperatures and along 6 days of reaction (in intervals of $24 \mathrm{~h}$ ) catalysed by $2 \mathrm{wt} . \% \mathrm{Mo}$ of $\mathrm{MoH}_{x}$ catalyst from MoNp precursor and accumulated turnover number (TON, as the number of moles of product that a mole of catalyst produces in the timeframe of the experiment or before being deactivated); (b) $\mathrm{NH}_{3}$ rate, in $\mu \mathrm{mol} \mathrm{h} \mathrm{h}^{-1} \mathrm{gmo}^{-1}$, at different temperatures $\left(200-550^{\circ} \mathrm{C}\right)$ in intervals of $1 \mathrm{~h}$. Note: $200 \mathrm{mg}$ catalyst, total flow-rate of $40 \mathrm{~mL} \mathrm{~min}{ }^{-1}, 3: 1 \mathrm{H}_{2}: \mathrm{N}_{2}$ ratio, $\mathrm{P}=1 \mathrm{~atm}$.

Mo centres act as active sites. Fig. $1 \mathrm{~b}$ indicates no $\mathrm{NH}_{3}$ production for temperatures below $300^{\circ} \mathrm{C}$, and $\mathrm{NH}_{3}$ rate of 1276 $\mu \mathrm{mol} \mathrm{h}{ }^{-1} \mathrm{gMo}^{-1}$ has been registered at $400^{\circ} \mathrm{C}$ and atmospheric pressure. Our values can be compared with previous experiments carried out by Ding and co-workers ${ }^{[18]}$ on supported molybdenum nitrides and carbides with $\mathrm{NH}_{3}$ rates of 275,1124 , and $1195 \mu \mathrm{mol} \mathrm{h}{ }^{-1} \mathrm{gmo}^{-1}$ for $\mathrm{MoN}_{x} / \mathrm{Al}_{2} \mathrm{O}_{3}, \mathrm{MoN}_{x} / \mathrm{ZSM}-5$, and $\mathrm{MoC}_{x} / \mathrm{ZSM}-5$, respectively. (In their case: $2.17 \mathrm{wt} . \% \mathrm{Mo}, 30 \mathrm{~mL}$ $\mathrm{min}^{-1}$ total flow-rate, and $400^{\circ} \mathrm{C}, 1 \mathrm{~atm}, 3: 1 \mathrm{H}_{2}: \mathrm{N}_{2}$ ratio operating conditions). A similar $\mathrm{NH}_{3}$ rate $\left(1250 \mu \mathrm{mol} \mathrm{h}^{-1} \mathrm{~g}^{-1}\right)$ was recently reported by Hosono and co-workers at similar reaction conditions, despite employing a Co-based material of LaCoSi. ${ }^{[19]}$ The $\mathrm{NH}_{3}$ production rate for our $\mathrm{MoH}_{x}$ catalyst derived from MoNp precursor increases to $9955 \mu \mathrm{mol} \mathrm{h}^{-1} \mathrm{gMo}^{-1}$ at the maximum temperature tested of $550^{\circ} \mathrm{C}$.

In order to define a model for the elucidation of the mechanistic events taking place during reaction, it should be noticed that, at high temperatures, hydride transfers to neighbouring siloxane bridges occur. ${ }^{[20]}$ This might lead to the formation of supported bipodal metal hydride species (see Scheme 1). Together with the presence of Mo-H stretching 


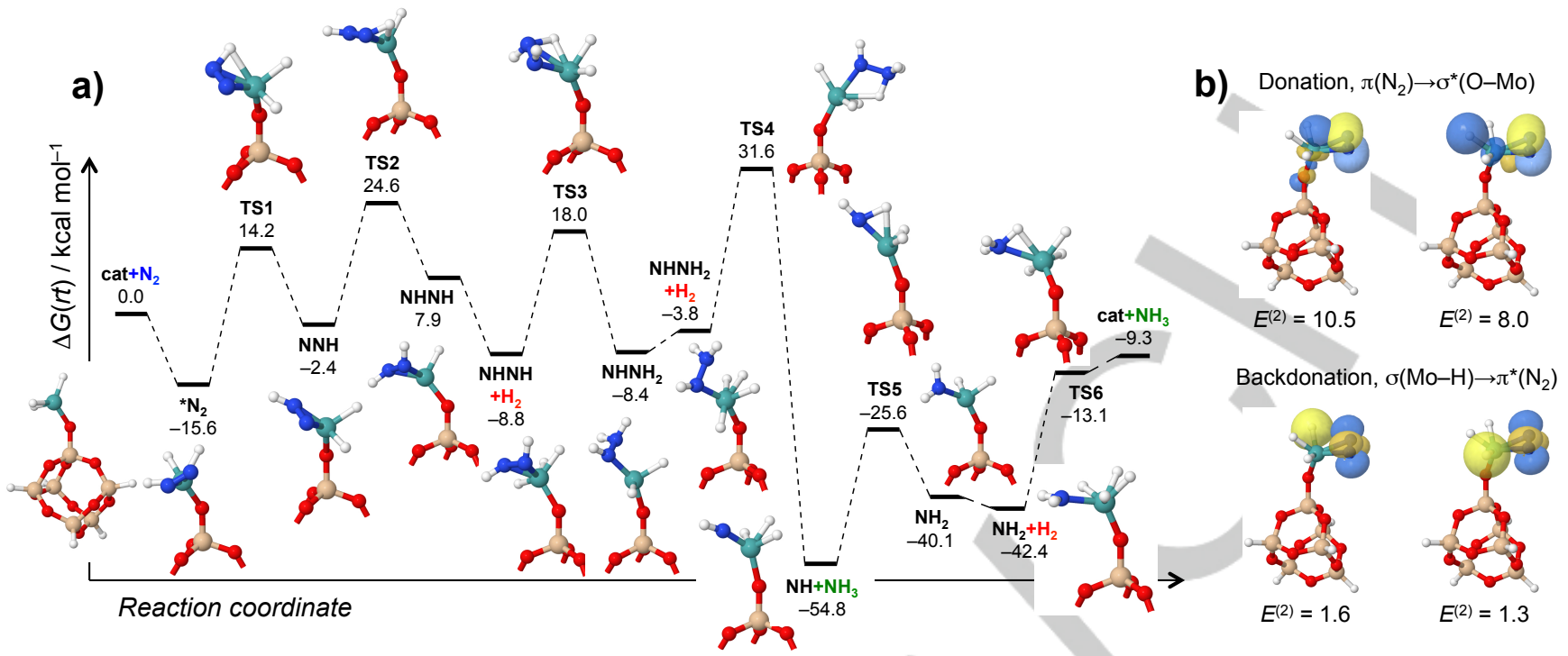

Figure 2. (a) Gibbs free energy profile (room temperature, in kcal mol-1), for $\mathrm{N}_{2}$-into- $\mathrm{NH}_{3}$ reaction mechanism catalysed by monopodal [( $\equiv \mathrm{Si}^{-\mathrm{O}-)}$ Mo $\left.{ }^{(\mathrm{IV})} \mathrm{H}_{3}\right]$. $\mathrm{Si}_{6} \mathrm{O}_{10} \mathrm{H}_{5}$ cluster has been used as silica model. Mo atom is assumed to switch between $\mathrm{Mo}^{(\mathrm{IV})}$ and $\mathrm{Mo}^{(\mathrm{VI})}$ oxidation states during the catalysis. Energy results are shown at the M06/TZVP//PBE/SVP(Si,O,H)/TZVP(Mo) computational level; (b) NBO interpretation, $E^{(2)}$ in kcal mol ${ }^{-1}$, for donation-backdonation interaction scheme in chemisorbed $\mathrm{N}_{2}$ on $\left[(\equiv \mathrm{Si}-\mathrm{O}-) \mathrm{Mo}^{(\mathrm{IV})} \mathrm{H}_{3}\right]$ (see Supporting Information for full computational details).

modes in the FTIR spectrum at Fig. S5, this makes us to hypothesise a set of $\left[(\equiv \mathrm{Si}-\mathrm{O}-) \mathrm{MoH}_{x}\right]$ species as potential catalysts to carry out our DFT modelling (see $\mathrm{SI}$ for full computational details). In this regard, we contemplate both, themonopodal (Fig. 2) and bipodal (Figs. S8 and S9) scenarios.

For the specific case of monopodal $\mathrm{Mo}^{(\mathrm{IV})}$-hydride on silica, e.g., $\left[(\equiv \mathrm{Si}-\mathrm{O}-) \mathrm{MoH}_{3}\right]$ as catalytic species, $\mathrm{N}_{2}$ gas is calculated to be spontaneously chemisorbed on the Mo centre, forming the $\left[(\equiv \mathrm{Si}-\mathrm{O}-) \mathrm{MoH}_{3}-\left(\eta^{2}-\mathrm{N}_{2}\right)\right]$ species with binding Gibbs free energy at room temperature of $-15.6 \mathrm{kcal} \mathrm{mol}^{-1}$. An interpretation from the Natural Bond Orbital (NBO) perspective points towards the existence of charge transfer from the occupied $\pi\left(N_{2}\right)$ orbital to the empty $\sigma^{*}(\mathrm{O}-\mathrm{Mo})$ orbitals, displaying orbital interaction energies of 10.5 and $8.0 \mathrm{kcal} \mathrm{mol}^{-1}$. Obeying a classical donation-backdonation scheme, ${ }^{[21]}$ synergic interactions from the occupied $\sigma(\mathrm{Mo}-\mathrm{H})$ orbital to the empty $\pi^{*}\left(\mathrm{~N}_{2}\right)$ are also seen, with $E^{(2)}=1.6$ and $1.3 \mathrm{kcal} \mathrm{mol}^{-1}$ (see Fig. 2b). As a result of this, a chemisorbed $\mathrm{N}_{2}$ molecule experiences an elongation of the $\mathrm{N} \equiv$ $\mathrm{N}$ triple bond by $0.09 \AA$ with respect the isolated molecule in gas phase $\left(d_{\mathrm{NN}}=1.112 \AA\right)$, which activates it for the subsequent hydrogenation steps. This notorious elongation is accompanied by an important redshift in $650 \mathrm{~cm}^{-1}$ of the $\mathrm{N} \equiv \mathrm{N}$ stretching vibrational mode.

Based on calculations, we hypothesise that $\mathrm{MoH}_{x}$ on silica catalysing $\mathrm{N}_{2}$-into- $\mathrm{NH}_{3}$ conversion follows a non-distal associative mechanistic route ${ }^{[22]}$ that consists in successive hydrogenations steps. For the specific case of [( $\left.\equiv \mathrm{Si}-\mathrm{O}-) \mathrm{MoH}_{3}\right]$, the first hydrogenation step involves one $\mathrm{H}$ transfer from $\mathrm{Mo}$ in $\left[(\equiv \mathrm{Si}-\mathrm{O}-) \mathrm{MoH}_{3}-\left(\eta^{2}-\mathrm{N}_{2}\right)\right]$ to $\mathrm{N}_{2}$ in [( $\left.\left.\equiv \mathrm{Si}-\mathrm{O}-\right) \mathrm{MoH}_{2}-\left(\eta^{2}-\mathrm{N}=\mathrm{NH}\right)\right]$ followed by a second transfer to get [( $\left.\equiv \mathrm{Si}-\mathrm{O}-) \mathrm{MoH}-\left(\eta^{2}-\mathrm{NHNH}\right)\right]$. These processes involve changes in the oxidation state of Mo, switching from (VI) to (IV) with the intermediacy of (V). Relative activation energies, $\Delta \Delta G_{\text {act }}$, for ${ }^{*} N_{2}$ state as reference, lie in 29.8 and $40.2 \mathrm{kcal} \mathrm{mol}^{-1}$, in each case. At this stage, the $\mathrm{Mo}^{(\mathrm{IV})}$ centre is assumed to gain one $\mathrm{H}_{2}$ molecule to follow-up with the reduction process. The further $\mathrm{H}$ transfer leads to [Mo]- $\mathrm{NHNH}_{2}$,

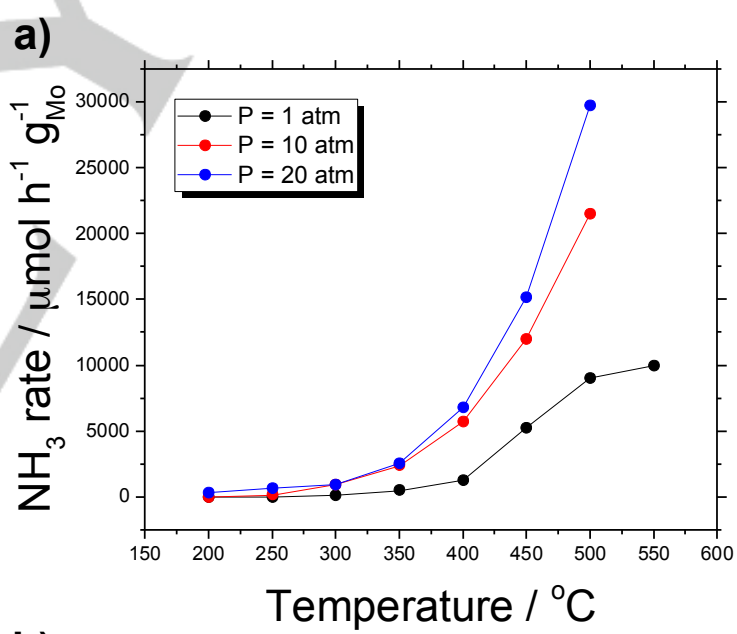

b)

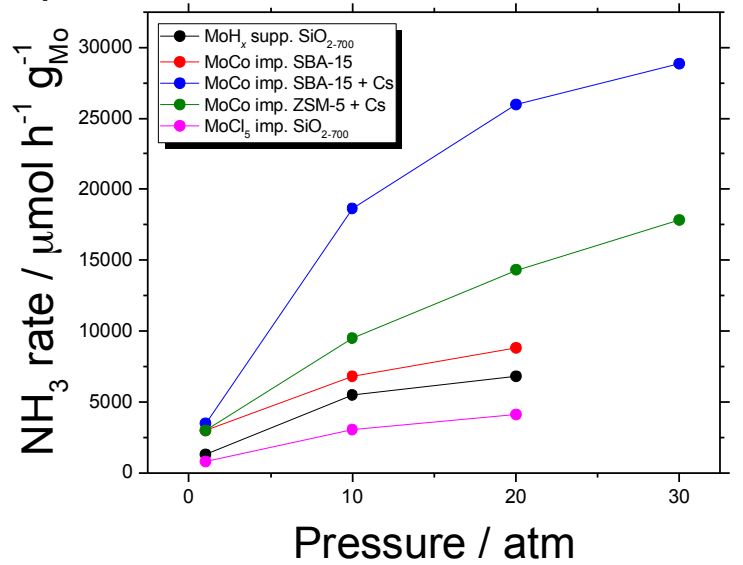

Figure 3. $\mathrm{NH}_{3}$ rate, in $\mu \mathrm{mol} \mathrm{h}{ }^{-1} \mathrm{gMo}^{-1}$ : (a) at different temperatures $\left(200-550^{\circ} \mathrm{C}\right)$ and pressures $(1,10,20 \mathrm{~atm})$ in intervals of $1 \mathrm{~h}$, catalysed by $2 \mathrm{wt} . \%$ Mo of 
$\mathrm{MoH}_{x}$ catalyst from MoNp precursor; (b) at different pressures (1-30 atm) and $400^{\circ} \mathrm{C}$, catalysed by 2 wt. $\%$ MoCo, $1: 1$ Mo:Co molar ratio, on different supports and in presence of caesium additive. Note: $200 \mathrm{mg}$ catalyst, total flow-rate of $40 \mathrm{~mL} \mathrm{~min}{ }^{-1}, 3: 1 \mathrm{H}_{2}: \mathrm{N}_{2}$ ratio.

and after the gain of a second $\mathrm{H}_{2}$ molecule, a $[\mathrm{Mo}]=\mathrm{NH}$ intermediate state is produced with the release of the first $\mathrm{NH}_{3}$ molecule. Relative activation energies for such steps reach 33.6 and $47.2 \mathrm{kcal} \mathrm{mol}{ }^{-1}$, respectively. The fact that the fourth $\mathrm{H}$ transfer from [Mo]-NHNH 2 to give [Mo]=NH (plus one $\mathrm{NH}_{3}$ molecule released) represents the limiting step of the whole reaction is in contrast with what has been observed for the hydrogenation of $\mathrm{N}_{2}$ on Ta-hydride supported on silica, but also with the general assumption that the rate-determining step is usually due to the first $\mathrm{H}$ transfer. ${ }^{[23]}$ Amination of the Mo active centre $([\mathrm{Mo}]=\mathrm{NH}$ state $)$ entails an energy drop to $-54.8 \mathrm{kcal} \mathrm{mol}^{-}$ 1. The fifth $\mathrm{H}$ transfer leads to $[\mathrm{Mo}]-\mathrm{NH}_{2}$ with a relative barrier of $29.2 \mathrm{kcal} \mathrm{mol}^{-1}$. Finally, the introduction of the third $\mathrm{H}_{2}$ molecule and the subsequent $\mathrm{NH}_{3}$ elimination with a barrier of $41.7 \mathrm{kcal}$ mol $^{-1}$ balances the $\mathrm{N}_{2}+3 \mathrm{H}_{2} \rightarrow 2 \mathrm{NH}_{3}$ chemical equation with a reaction energy of $-9.3 \mathrm{kcal} \mathrm{mol}^{-1}$ at the M06/TZVP//PBE/SVP(Si,O,H)/TZVP(Mo) computational level (see Supporting Information for full computational details). This is close to the experimental value of $-7.8 \mathrm{kcal} \mathrm{mol}^{-1}$ at standard conditions.

An exploration of the mechanism with the monopodal molybdenum pentakis-hydride, $\left[(\equiv \mathrm{Si}-\mathrm{O}-) \mathrm{Mo}^{(\mathrm{Vl})} \mathrm{H}_{5}\right]$, reveals a quite large reaction Gibbs free energy for the first $\mathrm{H}$ transfer, $43.8 \mathrm{kcal} \mathrm{mol}^{-1}$, so this reaction path is clearly dismissed. Alternative explorations using bipodal $\left[(\equiv \mathrm{Si}-\mathrm{O}-)_{2} \mathrm{Mo}^{(\mathrm{IV})} \mathrm{H}_{2}\right]$ and $\left[(\equiv \mathrm{Si}-\mathrm{O})_{2}-\mathrm{Mo}^{(\mathrm{Vl})} \mathrm{H}_{4}\right]$ species (see Figs. S8 and S9) reveal very similar energy profiles, with non-spontaneous $\mathrm{N}_{2}$-sorption (7.1 and $1.2 \mathrm{kcal} \mathrm{mol}^{-1}$ ), and limiting activation barriers of 47.9 and $45.1 \mathrm{kcal} \mathrm{mol}^{-1}$, respectively, also due to the fourth $\mathrm{H}$ transfer, i.e., analogous to TS4 at Fig. 2a.

The effect of pressure in $\mathrm{NH}_{3}$ rate, Fig. 3a, was also tested for $2 \mathrm{wt} . \% \mathrm{Mo}$ of $\mathrm{MoH}_{x}$ catalyst from MoNp precursor. In a range of temperatures between 200 and $550^{\circ} \mathrm{C}$ and different pressures of 1,10 , and $20 \mathrm{~atm}$, an increase of $\mathrm{NH}_{3}$ production was seen with the pressure, e.g., $\mathrm{NH}_{3}$ rates at $500^{\circ} \mathrm{C}$ have been measured experimentally as 9011, 21496, and $29696 \mu \mathrm{mol} \mathrm{h}^{-1} \mathrm{gMo}^{-1}$, respectively.

In the search for increased $\mathrm{NH}_{3}$ rate activities, a new set of catalysts were prepared and tested by incipient aqueous wetness impregnation of different structured supports. In order to prepare impregnated MoCo catalysts, mesoporous silica SBA-15 and lower-cost microporous zeolite ZSM-5 were used and mixed with ammonium heptamolybdate hydrate and cobalt nitrate hexahydrate, with 2 wt.\% Mo loading and 1:1 Mo:Co molar ratio. Fig. $3 b$ gathers $\mathrm{NH}_{3}$ rates at different pressures and $400^{\circ} \mathrm{C}$, comparing $\mathrm{NH}_{3}$ production data by action of these different examined catalysts: i) 2 wt. $\% \mathrm{Mo}$ of $\mathrm{MoH}_{x}$ catalyst from MoNp precursor supported on silica $\mathrm{SiO}_{2-700}$ (black); ii) 2 wt.\% Mo of MoCo catalyst impregnated on mesoporous silica SBA-15 (red); iii) in microporous zeolite ZSM-5 and in presence of caesium additive (green); and iv) in mesoporous silica SBA-15 and in presence of caesium additive (blue). These catalysts have been systematically tested at $1,10,20$, and eventually 30 atm of pressure in intervals of $1 \mathrm{~h}$. In addition, $2 \mathrm{wt} . \%$ Mo coming from $\mathrm{MoCl}_{5}$ impregnated on silica $\mathrm{SiO}_{2-700}$ (violet) has been also prepared and tested for comparison with our welldefined single site catalyst.
According to measurements, the inclusion of cobalt cocatalyst and the use of structured supports increases $\mathrm{NH}_{3}$ rates. This production growth is especially relevant in the presence of alkali caesium additive, reaching $28356 \mu \mathrm{mol} \mathrm{h}^{-1} \mathrm{~g}_{\mathrm{Mo}}{ }^{-1}$ under 30 atm and $400^{\circ} \mathrm{C}$ operating conditions and using SBA-15 support. (Change of support to ZSM-5 and under the same operating conditions, drops $\mathrm{NH}_{3}$ rate to $17850 \mu \mathrm{mol} \mathrm{h}^{-1} \mathrm{gmo}^{-1}$ ). In addition, the very low $\mathrm{NH}_{3}$ rate of impregnated $\mathrm{MoCl}_{5}$ on silica catalyst confirms the fundamental role played by Co co-catalyst in the $\mathrm{N}_{2}$ fixation performance. In this sense, we are currently working on bi-metallic well-defined systems with the aim to understand the chemistry of this type of materials.

In summary, a set of molybdenum on solid support materials have been prepared and tested as catalysts for $\mathrm{N}_{2}$ into- $\mathrm{NH}_{3}$ conversion via chemical hydrogenation. Single-atom Mo-hydrides derived from well-defined, monopodal Moneopentyl precursor, [( $\equiv$ Si-O- $)$ Mo $\left.\left(\equiv \mathrm{C}_{-}{ }^{t} \mathrm{Bu}\right)(\mathrm{Np})_{2}\right]$, have demonstrated proactive behaviours for $\mathrm{NH}_{3}$ synthesis at atmospheric pressure and temperatures above $300^{\circ} \mathrm{C}$. This material, containing only $2 \mathrm{wt} . \% \mathrm{Mo}$, has proven very stable catalytic activities with growing accumulated turnover numbers during operation. The reaction mechanism for $\mathrm{N}_{2}$-into- $\mathrm{NH}_{3}$ conversion catalysed by monopodal $\left[(\equiv \mathrm{Si}-\mathrm{O}-) \mathrm{Mo}^{(\mathrm{IV})} \mathrm{H}_{3}\right]$ and bipodal $\left[(\equiv \mathrm{Si}-\mathrm{O}-)_{2} \mathrm{Mo}^{(\mathrm{IV})} \mathrm{H}_{2}\right]$ and $\left[(\equiv \mathrm{Si}-\mathrm{O}-)_{2} \mathrm{Mo}^{(\mathrm{VI})} \mathrm{H}_{4}\right]$ species has been studied via DFT tools, suggesting maximum relative activation barriers of ca. $45 \mathrm{kcal} \mathrm{mol}^{-1}$. Inclusion of cobalt cocatalyst impregnated on mesoporous SBA-15 support plus alkali caesium additive increases $\mathrm{NH}_{3}$ rates. Amongst all the studied materials, 2 wt.\% Mo of MoCo catalyst (1:1 Mo:Co molar ratio) impregnated on mesoporous silica SBA-15 plus caesium additive have produced ca. $3.5,19,26$, and $29 \cdot 10^{3} \mu \mathrm{mol} \mathrm{h}^{-1} \mathrm{~g}_{\mathrm{Mo}}{ }^{-}$ ${ }^{1}$ of $\mathrm{NH}_{3}$ under $1,10,20$, and $30 \mathrm{~atm}$ of pressure (at $400^{\circ} \mathrm{C}$ ). Finally, we expect that this work would stimulate further interests in order to achieve greater progresses in this hot research topic.

\section{Acknowledgements}

Authors acknowledge SABIC (Saudi Basic Industries Corporation) and King Abdullah University of Science and Technology (KAUST) for support. Gratitude is also due to the KAUST Supercomputing Laboratory using the supercomputer Shaheen II for providing the computational resources. A.P. also thanks the Spanish MINECO for a project CTQ2014-59832-JIN.

Keywords: $\mathrm{N}_{2}$ fixation $\cdot \mathrm{NH}_{3}$ synthesis $\cdot$ Haber-Bosch alternative $\cdot$ molybdenum-based catalyst $\bullet$ in-silico design

[1] E. Worrell, D. Phylipsen, D. Einstein, N. Martin, Energy Use and Energy Intensity of the U.S. Chemical Industry, 2010. Available, free of charge, at: https://www.energystar.gov

[2] L. E. Apodaca, Mineral Commodity Summaries 2014, U.S. Department of the Interior, U.S. Geological Survey. Available, free of charge, at: https://minerals.usgs.gov

[3] R. D. Milton, R. Cai, S. Abdellaoui, D. Leech, A. L. De Lacey, M. Pita, S. D. Minteer, Angew. Chem. Int. Ed. 2017, 56, 2680.

[4] J. G. J. Olivier, G. Janssens-Maenhout, M. Muntean, J. A. H. W. Peters, Trends in Global $\mathrm{CO}_{2}$ Emissions, 2015 Report, Background Studies, PBL Netherlands Environmental Assessment Agency, page 4. Available, free of charge, at: http://edgar.jrc.ec.europa.eu

[5] F. Haber, R. Le Rossignol, Z. Elektrochem. Angew. Phys. Chem. 1913, 19, 53.

[6] T. Kandemir, M. E. Schuster, A. Senyshyn, M. Behrens, R. Schlögl, Angew. Chem. Int. Ed. 2013, 52, 12723. 
[7] H. Liu, Chin. J. Catal. 2014, 35, 1619

[8] a) M. Appl, Ammonia. Principles and Industrial Practice. Wiley-VCH, Weinheim, 1999; b) M. Kitano, S. Kanbara, Y. Inoue, N. Kuganathan, P. V. Sushko, T. Yokoyama, M. Hara, H. Hosono, Nat. Commun. 2015, 6, 6731 .

[9] Current market prices for metals can be checked on-line at: http://www.infomine.com

[10] J. D. A. Pelletier, J.-M. Basset, Acc. Chem. Res. 2016, 49, 664.

[11] a) K. Asakura, M. Nishimura, Y. Iwasawa, J. Mol. Catal. 1989, 55, 159; b) E. Mazoyer, N. Merle, A. de Mallmann, J.-M. Basset, E. Berrier, L. Delevoye, J. F. Paul, C. P. Nicholas, R. M. Gauvin, M. Taoufik, Chem. Commun. 2010, 46, 8944.

[12] a) V. Vidal, A. Theolier, J. Thivolle-Cazat, J.-M. Basset, Science 1997, 276, 99; b) J.-M. Basset, C. Coperet, L. Lefort, B. M. Maunders, O Maury, E. Le Roux, G. Saggio, S. Soignier, D. Soulivong, G. J. Sunley, M. Taoufik, J. Thivolle-Cazat, J. Am. Chem. Soc. 2005, 127, 8604; c) F Blanc, C. Coperet, J. Thivolle-Cazat, J.-M. Basset, Angew. Chem. Int. Ed. 2006, 45, 6201; d) Y. Chen, E. Abou-Hamad, A. Hamieh, B Hamzaoui, L. Emsley, J.-M. Basset, J. Am. Chem. Soc. 2015, 137, 588.

[13] P. Avenier, M. Taoufik, A. Lesage, X. Solans-Monfort, A. Baudouin, A. de Mallmann, L. Veyre, J.-M. Basset, O. Eisenstein, L. Emsley, E. A. Quadrelli, Science 2007, 317, 1056.

[14] J. Li, S. Li, Angew. Chem. Int. Ed. 2008, 47, 8040.

[15] X. Solans-Monfort, C. Chow, E. Goure, Y. Kaya, J.-M. Basset, M. Taoufik, E. A. Quadrelli, O. Eisenstein, Inorg. Chem. 2012, 51, 7237.

[16] Molybdenum compounds have demonstrated to be promising catalysts for homogeneous $\mathrm{N}_{2}$ fixation. Some works to be highlighted are: a) D. V. Yandulov, R. Schrock, Science 2003, 301, 76; b) W. W. Weare, X. Dai, M. J. Byrnes, J. M. Chin, R. R. Schrock, P. Müller, PNAS 2006, 103 17099; c) K. Arashiba, Y. Miyake, Y. Nishibayashi, Nat. Chem. 2011, 3, 120.

[17] R. P. Saint-Arroman, M. Chabanas, A. Baudouin, C. Copéret, J.-M. Basset, A. Lesage, L. Emsley, J. Am. Chem. Soc. 2001, 123, 3820.

[18] N. Liu, L. Nie, N. Xue, H. Dong, L. Peng, X. Guo, W. Ding, ChemCatChem 2009, 2, 167.

[19] Y. Gong, J. Wu, M. Kitano, J. Wang, T.-N. Ye, J. Li, Y. Kobayashi, K. Kishida, H. Abe, Y. Niwa, H. Yang, T. Tada, H. Hosono, Nat. Catal. 2018, 1, 178.

[20] a) F. Rataboul, A. Baudouin, C. Thieuleux, L. Veyre, C. Copéret, J. Thivolle-Cazat, J.-M. Basset, A. Lesage, L. Emsley, J. Am. Chem. Soc 2014, 126, 12541; b) N. Maity, S. Barman, E. Callens, M. K. Samantaray, E. Abou-Hamad, Y. Minenkov, V. D'Elia, A. S. Hoffman, C. M. Widdifield, L. Cavallo, B. C. Gates, J.-M. Basset, Chem. Sci. 2016, 7, 1558.

[21] L. M. Azofra, C. Sun, L. Cavallo, D. R. MacFarlane, Chem. Eur. J. 2017, 23, 8275 .

[22] a) J. S. Anderson, J. Rittle, J. C. Peters, Nature 2013, 501, 84; b) L. M. Azofra, N. Li, D. R. MacFarlane, C. Sun, Energy Environ. Sci. 2016, 9 , 2545 ; c) B. H. R. Suryanto, C. S. M. Kang, D. Wang, C. Xiao, F. Zhou, L. M. Azofra, L. Cavallo, X. Zhang, D. R. MacFarlane, ACS Energy Lett. 2018, 3,1219,

[23] H.-P. Jia, E. A. Quadrelli, Chem. Soc. Rev. 2014, 43, 547.

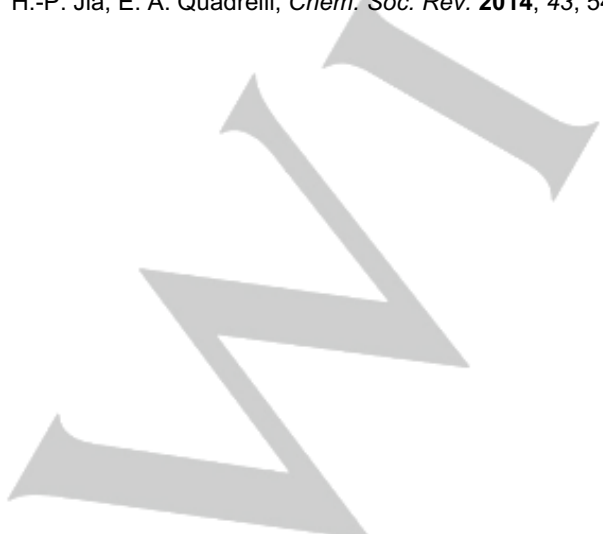


Table of Contents

\section{COMMUNICATION}

$\mathrm{N}_{2}$-into- $\mathrm{NH}_{3}$ conversion is one of the most globally important processes in the chemical industry. In this work, we present a set of molybdenum on solid support materials catalysing $\mathrm{N}_{2}$ fixation under atmospheric pressure accompanied by DFT analysis for an in-depth elucidation of the mechanistic events taking place during reaction
A procedure for catalytic $\mathrm{N}_{2}$ fixation

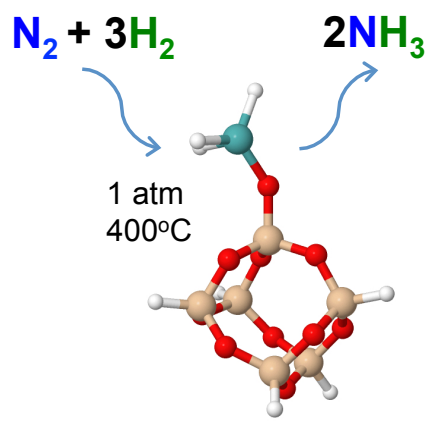

L. M. Azofra, * N. Morlanés, A. Poater, M. K. Samantaray, B. Vidjayacoumar, K. Albahily, L. Cavallo* and J.-M. Basset* $^{*}$

Page No. XXXX - Page No. XXXX

Molybdenum on solid support materials for catalytic hydrogenation of $\mathrm{N}_{2}$-into- $\mathrm{NH}_{3}$ 